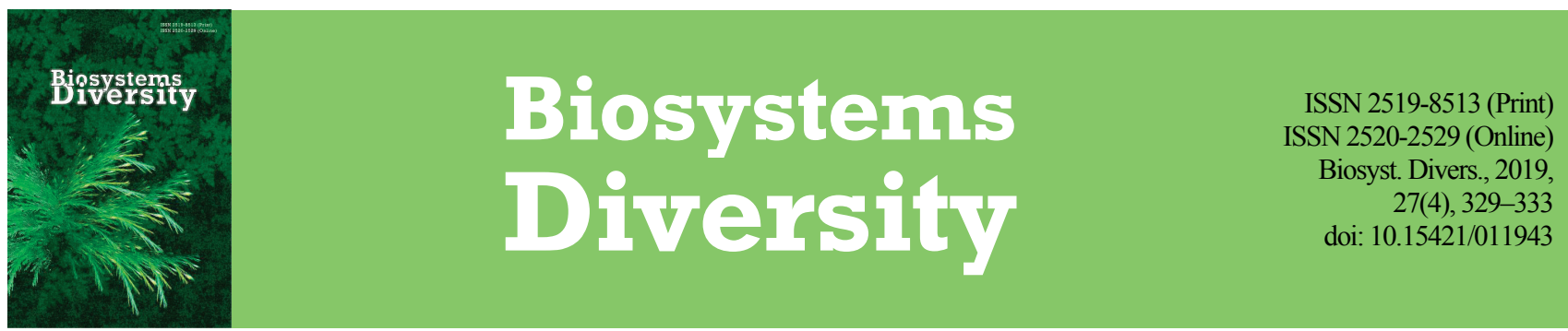

\title{
Patterns of mercury accumulation in the organs of bank vole Myodes glareolus (Rodentia, Cricetidae)
}

\author{
V. A. Gremyachikh*, D. A. Kvasov**, E. S. Ivanova*** \\ *Papanin Institute for Biology of Inland Water, Russian Academy of Sciences, Russia \\ **Center for Hygiene and Epidemiology in the Voronezh Region, Voronezh, Russia \\ ***Cherepovets State University, Cherepovets, Russia
}

Article info

Received 02.10.2019

Received in revised form 07.11 .2019

Accepted 09.11.2019

Institute of Biology of Inland Waters named after

I. D. Papanin RAS, Borok

Yaroslavl region, 152742,

Russia. Tel.: + 7-910-826-60-86

E-mail:grva@ibiw.ru

Center for Hygiene and

Epidemiology in the Voronezh

Region, Cosmonauts st., 21,

Voronezh, 394038, Russia.

Tel.: +7-904-210-05-92

E-mail:kvasovrn@gmail.com

Cherepovets State University

Lunacharskyst., 5 ,

Cherepovets, 162600, Russia..

Tel.: +7-921-135-95-25.

E-mail: stepinaelena@yandex.ru Gremyachikh, V. A., Kvasov, D. A., \& Ivanova, E. S. (2019). Patterns of mercury accumulation in the organs of bank vole
Myodes glareolus (Rodentia, Cricetidae). Biosystems Diversity, 27(4), 329-333. doi:10.15421/011943

Mercury $(\mathrm{Hg})$ and its compounds are among the most hazardous environmental pollutants with a high cumulative potential and they can have toxic effects on human and animal health even in low concentrations. Due to the increasing rate of human economic activity and the increase in the amount of $\mathrm{Hg}$ in the total cycling of matter, the study of its distribution, transformation, redistribution and accumulation in the abiotic and biotic components of various ecosystems remains important up to the present time. We assessed the content of metal in organs and tissues of the bank vole Myodes (Clethrionomys) glareolus Schreber, 1780 (Rodentia, Cricetidae), a widespread small rodent, caught in different biotopes of forest-steppe and steppe zones of Voronezh region. Measurements of $\mathrm{Hg}$ in samples were carried out with a mercury analyzer RA-915+ with the accessory PYRO (Lumex) using the atomic absorption method of cold steam without preliminary sample preparation (the lower limit of mercury detection in samples was $0.001 \mathrm{mg} / \mathrm{kg}$ ). The sample size was 344 specimens. Mean $\mathrm{Hg}$ concentrations ranged from values below the analytical determination threshold to $0.887 \mathrm{mg} / \mathrm{kg}$ dry weight in the kidneys, 0.411 in the liver, 0.031 in the muscle tissue, and 0.040 in the brain. A positive correlation was found between the metal content in all possible pairs of organs (except for the "muscle brain" pair) and a weak negative correlation was found between the $\mathrm{Hg}$ level and the mass of the animals. Hg concentrations in the studied organs did not differ between males and females. The metal content in the liver and kidneys of voles from the forest-steppe zone was significantly higher than in those from the steppe zone. Among all studied biotopes (meadow, pine and mixed forest, shrub thickets), the lowest concentrations were observed in animals living in pine forests, while the highest one - in more humidified bush thickets. During the vegetation season, there was a decrease in the average values of animal body mass in the samples and an increase in the content of $\mathrm{Hg}$ in the liver and kidneys. The results of the study are relevant in the assessment of atmospheric mercury pollution of terrestrial ecosystems using small mammals, such as Myodes glareolus, as a model object.

Keywords: terrestrial ecosystems pollution; heavy metals; mercury; small mammals; rodents.

\section{Introduction}

Mercury $(\mathrm{Hg})$, one of the most common and toxic heavy metals, has unique physical and chemical properties that underlie its ubiquitous presence in the environment and its high degree of biomagnification (Kolka et al., 2011; Eagles-Smith et al., 2016). The main share of Hg emissions into the atmosphere is in elementary gaseous form. Its volatility and long lifetime (one year on average) are responsible for the global distribution of the metal in the atmosphere (Lindberg et al., 2007; Gilmour et al., 2013; HsuKim et al., 2013). The study of intake, distribution and accumulation of $\mathrm{Hg}$ in the abiotic and biotic components of aquatic and terrestrial ecosystems has not lost its urgency up to date. This is due to the increasing scale of human economic activity and the increase in the amount of mercury involved in the total cycle of matter (Mason \& Sheu, 2002; Selin, 2009). Most work on the subject has been carried out on water bodies of different genesis. In terrestrial ecosystems, the $\mathrm{Hg}$ content in the organs and tissues of species whose habitats are confined to water bodies has been determined (Cristol et al., 2008; Gann et al., 2015; Rutkowska et al., 2019). However, studies conducted on small insectivores, rodents and predators of various trophic levels have shown that terrestrial ecosystems may have an alternative route of mercury transmission through food webs, and soil may be the source of its methylated derivatives (Talmage \& Walton, 1993; Tjerngren et al., 2012; Oswald et al., 2014).

The bank vole Myodes (Clethrionomys) glareolus Schreber, 1780 is a widespread and abundant, sometimes dominant species of small mammal, grouped into one size group according to the similarity of the sizes of their home ranges and the comparability of the scales of their local communities with the scales of phytocenoses (Shchipanov et al., 2010). These animals exhibit a high level of metabolism. Their contribution to the dynamics of ecosystems is significant, as well as their dependence on food and temperature characteristics of the environment. Small mammals occupying various ecological niches and specializing in food resources produced by the ecosystem (herbage, seeds, invertebrates) are traditional objects of monitoring. They are used as a model group of animals in the study of the effects of various environmental changes, including those related to human impact (Talmage \& Walton, 1993; Sánchez-Chardi et al., 2009; Tavshunsky et al., 2017). Small mammals do not migrate over long distances, which makes them suitable targets for the assessment of heavy metal pollution, including mercury, which is of global importance (SánchezChardi \& López-Fuster, 2009; Sneddon et al., 2009; Petkovsek et al., 2014).

Most of the studies on the assessment of pollution of terrestrial ecosystems using small mammals were carried out in environmentally unsafe areas associated with the presence of local sources of $\mathrm{Hg}$ (Bull et al., 1977; Talmage \& Walton, 1993; Sánchez-Chardi et al., 2009). However, for a general understanding of the functioning of biota it is equally important to study regions exposed mainly to atmospheric mercury pollution, but which are fairly diverse in respect of conditions in the plant and animal communities that constitute them, in particular, the Voronezh region.

The aim of this work is to study the physiological and environmental features, as well as the dynamics of mercury accumulation in the organs of bank voles from different biotopes of Voronezh region exposed to atmospheric pollution by this heavy metal. 


\section{Materials and methods}

Voronezh region is located within the area of two natural zones: forest-steppe and steppe. Its vegetation consists of insular forests, interspersed with vast steppe areas, which become dominant as we move to the South. The diversity of natural landscapes is enhanced by anthropogenic changes (agrocenoses, artificial forest ranges, urban phytocenoses). The forest cover of the Voronezh region has significantly decreased due to human activity and is currently about 11\% (Fedotov, 2013). Forests, mainly oakeries, are concentrated on watersheds, being confined to the right banks of rivers. In the river valleys, floodplain forests are represented mainly by oakeries and alder groves. Pine plantations are confined to the terraces above the floodplain. Meadow communities are mainly secondary, located in floodplains of large rivers.

Twelve investigated districts of Voronezh region belong, respectively, to the following zones: Semilukskiy (1), Ramonskiy (2), Verkhnekhavskiy (3), Voronezh City (4), Novousmanskiy (5) to the western forest-steppe zone; Anninskiy (6) - to the eastern forest-steppe zone; Povorinskiy (7), Novokhoperskiy (8), Verkhnemamonskiy (9) - to the northern steppe zone; Rossoshanskiy (10), Petropavlovskiy (11), Bogucharskiy (12) - to the southern steppe zone.

The humidity factor $(\mathrm{Kh})$, proposed by M. I. Budyko and calculated as the ratio of annual precipitation in $\mathrm{mm}$ to the sum of average daily temperatures above $+10^{\circ} \mathrm{C}$ was employed as a specification of geographical zones (Fedotov, 2013). According to the values of this index, the northwestern districts of the region experience excess moisture (2, 3 and 5) while districts 10 and 11 are characterized by a noticeable lack of moisture.

To assess the mercury load on the districts, natural zones and different plant communities (biotopes), we studied the bank vole, a cricetid rodent, Myodes glareolus (Clethrionomys glareolus), of the genus of forest voles. The southern border of its distribution in the European part of Russia passes through island and floodplain woods of Voronezh, Saratov and Samara regions. This species inhabits various types of forests. The size of home ranges in adult females varies from 0.04 to 0.10 ha, while in males - from 0.10 to 0.80 ha, covering ranges of several females. Animals are active year-round and round-the-clock. M. glareolus is considered as a euryphage species (Emel'yanova, 2008). Its diet includes all parts of herbaceous plants and shrubs, leaves, shoots, bark, fruits and seeds of trees and shrubs, mosses, lichens, fungi, invertebrates and even small vertebrates. The enormous adaptation ability of the bank vole to consume a variety of food items switching easily from preferred food items to replacement ones due to changes of nutritive base is well-known. Regional, biotopic and seasonal differences are observed in the diet of the bank vole, depending on the differences in supply of main food items. No significant sexual or age differences in the diet of the animals were found. The breeding season begins in March-April, sometimes still under snow, ending in August-September. The female produces 3-4 broods per year with 5-6 youngs in each. Offspring of the first brood produce up to 3 broods during the summer, the second one $-1-2$, and the third one (in favourable years) 1. In the wild, voles live about $0.5-1.5$ years.

The bank voles were sampled from March to October 2014-2017 in different biotopes of the forest-steppe and steppe zones of the region, the choice of which was determined by life habits of the animal. The species prefers deciduous forests, inhabiting lightened areas at the forest edges and open forests, from where it comes to feed on borders of meadows and fields. The following biotopes were studied: meadows, pine and mixed forests, confined to watersheds or river floodplains, and shrub thickets.

A total of 344 specimens of the bank voles were captured with the traditional method of trap-lines. Gero crush traps were used for sampling, with pieces of bread soaked in unrefined sunflower oil serving as a bait. The traps were placed in a line of 100 units, the captured rodents being collected every 24 hours. Sampling, storage, sample preparation, and determination of mercury (in three replications) in dry muscle, liver, kidney, and brain samples were performed using the standard previously described technique (Komov et al., 2017) in compliance with all necessary safety requirements. The $\mathrm{Hg}$ concentration in the samples was measured using a RA-915+ mercury analyzer with PYRO add-on device (Lumex) by the cold vapour atomic absorption method (the lower limit of mercury detection in the samples was $0.001 \mathrm{mg} / \mathrm{kg}$ ). The accuracy of analytical measurement methods was controlled using certified biological material DORM-2 and DOLM-2 (Institute of Environmental Chemistry, Ottawa, Canada).

Data on $\mathrm{Hg}$ concentrations are presented as mean values with standard errors $(x \pm S E)$, indicating also ranges (min-max). Statistical analysis of the results was performed using the program package Statistica 12 (StatSoft, USA, 2013). The nonparametric Spearman rank correlation coefficient (RS) was used to estimate correlations between the studied parameters that did not have normal distribution (Shapiro-Wilke test), and the Kruskal-Wallis median test was used to estimate differences between the samples; the differences were considered significant at $\mathrm{P}<0.05$.

\section{Results}

The $\mathrm{Hg}$ content in various organs of $M$. glareolus $(\mathrm{mg} / \mathrm{kg}$ dry weight) varied from values below the analytical determination threshold to 0.887 in the kidneys, 0.411 in the liver, 0.031 in the muscle tissue and 0.040 in the brain. On average, it yielded $0.085,0.028,0.007$ and 0.004 , respectively (Table 1). Mercury concentrations in all the organs differed significantly (Fig. 1), with the following ranking: $\left[\mathrm{Hg}_{\text {kidneys }}\right]>\left[\mathrm{Hg}_{\text {liver }}\right]>$ $\left[\mathrm{Hg}_{\text {muscle }}\right]>\left[\mathrm{Hg}_{\text {brain }}\right]$.

In bank voles, a positive correlation was revealed between the concentrations of $\mathrm{Hg}$ in all possible pairs of organs, except for the pair "muscle - brain" (RS: $0.18-0.71$ at $\mathrm{P}<0.05$, the highest correlation coefficient was obtained for the pair "liver-kidney") and a weak negative correlation - between the values of the index in the kidneys and the body mass of animals $(\mathrm{RS}=-0.12, \mathrm{P}<0.05)$. The metal content in the organs of males and females did not differ significantly.

The highest average $(0.13$ and $0.19 \mathrm{mg} / \mathrm{kg}$ dry weight $)$ and individual $(0.887$ and 0.543$)$ concentrations of $\mathrm{Hg}$ in the kidneys were observed for voles from the districts 2 and 5 of the forest-steppe zone (Table 1). The lowest values were obtained for specimens from the districts 1,7 , and 8 (the last two belong to the steppe zone) the sample means being $0.045,0.001,0.046$ and individual values $-0.172,0.003$, 0.133 , respectively (Fig. 2). The metal content in the liver and kidneys of voles from the western forest-steppe and southern steppe zones was significantly higher than in the northern steppe zone. The same patterns were observed when comparing $\mathrm{Hg}$ concentrations in the liver in pooled samples from forest-steppe and steppe zones $(\mathrm{P}<0.02)$ (Fig. 3).

Concentrations of $\mathrm{Hg}$ in the liver and kidneys of the bank vole varied depending on the habitat. In the liver of pine forest animals $(0.006 \mathrm{mg} / \mathrm{kg}$ dry weight) they were the lowest $(\mathrm{P}<0.002)$ as compared to those in all other biotopes (0.019-0.032). The metal content in the kidneys of animals caught in bush thickets $(0.091)$ significantly exceeded $(\mathrm{P}<0.004)$ that for individuals inhabiting meadows (0.054) and pine forests (0.049) (Fig. 4). Significant differences $(\mathrm{P}<0.005)$ in $\mathrm{Hg}$ concentrations in the liver of rodents living in floodplain forests $(0.056)$ and bushes $(0.091)$ were observed within the limits of the steppe zone. During the growing season, there was a change in the average mass and metal content in animal organs. The weight of voles decreased from spring to autumn, while the concentrations of $\mathrm{Hg}$ in the liver and kidneys increased.

\section{Discussion}

The average concentrations of total $\mathrm{Hg}$ in the organs of bank voles caught in the study region (0.004-0.085 $\mathrm{mg} / \mathrm{kg}$ dry weight) are comparable to literature data for small mammals, whose habitats are not adjacent to sources of mercury pollution, and they are lower than those in sympatric insectivores, due to the specific features of their nutritive base. The average metal content in the organs of the bank voles from various biotopes of the Voronezh State Natural Biosphere Reserve was $0.005-0.090 \mathrm{mg} / \mathrm{kg}$ dry weight, in the common shrew (Sorex araneus) $0.041-0.500$, in the Eurasian pygmy shrew (Sorex minutus) - 0.0410.209 (Komov et al., 2010). In the animals of the Forest Park "Zelyonaya Roshcha" (Green grove) located in the suburban area of Cherepovets (Vologda region, Russia) average $\mathrm{Hg}$ content ranged as follows: bank vole $-0.001-0.140$, common shrew $-0.005-0.350$ (Komov et al., 2017). In the liver of rodent species (Merriam's kangaroo rat Dipo- 
domys merriami, desert pocket mouse Chaetodipus penicillatus, cactus mouse Peromyscus eremicus, desert woodrat Neotoma lepida) captured in desert areas near Las Vegas, Nevada, USA, this index ranged from 0.002 to 0.01 (Gerstenberger et al., 2006). In the kidneys and liver of a North American rodent, the deer mouse Peromyscus maniculatus, it was $0.035-0.100$ and $0.36-0.43$, respectively (Vucetich et al., 2001). $\mathrm{Hg}$ concentrations in the organs of the bank voles of Voronezh region are lower than in small mammals from contaminated habitats. In the

Table 1

Mercury content in the organs of the bank voles from Voronezh region kidneys of individuals of this species captured in the UK at different distances (less than 0.05 and $10-30 \mathrm{~km}$ ) from an industrial area of chlor-alkali works, the $\mathrm{Hg}$ contents was 0.35 and $0.08 \mathrm{mg} / \mathrm{kg}$ of raw mass (on dry basis, the values would be higher) (Bull et al., 1977). Average concentrations in the kidneys of the white-footed mouse Peromyscus leucopus and the short-tailed shrew Blarina brevicauda from industrial areas of the United States were $1.16 \pm 1.16$ and $38.8 \pm 24.6 \mathrm{mg} / \mathrm{kg}$ wet weight, respectively (Talmage \& Walton, 1993).

\begin{tabular}{|c|c|c|c|c|c|c|c|}
\hline \multirow{2}{*}{ District } & \multirow{2}{*}{$\mathrm{n}$} & \multirow{2}{*}{ Animal weight, mg } & \multicolumn{4}{|c|}{$\mathrm{Hg}, \mathrm{mg} / \mathrm{kg}$ dry weight } & \multirow{2}{*}{ Date } \\
\hline & & & muscle & liver & kidneys & brain & \\
\hline \multicolumn{8}{|c|}{ Western forest-steppe zone } \\
\hline \multirow{2}{*}{1} & \multirow[b]{2}{*}{26} & $22.7 \pm 0.4$ & \multirow[b]{2}{*}{-} & $0.018 \pm 0.004$ & $0.045 \pm 0.009$ & \multirow[b]{2}{*}{-} & 03.2015 , \\
\hline & & $20.0-29.0$ & & $0.001-0.094$ & $0.001-0.172$ & & 03.2017 \\
\hline \multirow{2}{*}{2} & \multirow{2}{*}{55} & $18.2 \pm 0.9$ & \multirow[b]{2}{*}{-} & $0.079 \pm 0.009$ & $0.134 \pm 0.019$ & $0.005 \pm 0.001$ & 09.2014, \\
\hline & & $7.0-34.5$ & & $0.000-0.411$ & $0.007-0.887$ & $0.000-0.012$ & 09.2016 \\
\hline & & $17.2 \pm 0.5$ & \multirow{2}{*}{-} & $0.012 \pm 0.002$ & $0.070 \pm 0.014$ & $0.004 \pm 0.001$ & \multirow{2}{*}{10.2014} \\
\hline 3 & 82 & $6.5-42.5$ & & $0.000-0.100$ & $0.000-0.730$ & $0.000-0.040$ & \\
\hline 4 & 3 & $18.8 \pm 0.9$ & \multirow{2}{*}{-} & $0.029 \pm 0.009$ & $0.062 \pm 0.002$ & \multirow{2}{*}{-} & 05.2015 \\
\hline 4 & 3 & $17.5-20.5$ & & $0.011-0.018$ & $0.039-0.065$ & & 12.2017 \\
\hline \multirow{2}{*}{5} & \multirow{2}{*}{29} & $20.7 \pm 0.7$ & $0.008 \pm 0.002$ & $0.044 \pm 0.006$ & $0.185 \pm 0.027$ & $0.002 \pm 0.001$ & \multirow{2}{*}{05.2015} \\
\hline & & $14.5-31.5$ & $0.000-0.012$ & $0.000-0.093$ & $0.009-0.543$ & $0.000-0.004$ & \\
\hline \multicolumn{8}{|c|}{ Eastern forest-steppe zone } \\
\hline \multirow{2}{*}{6} & \multirow{2}{*}{15} & $20.7 \pm 0.7$ & $0.003 \pm 0.001$ & $0.024 \pm 0.009$ & $0.064 \pm 0.022$ & $0.003 \pm 0.001$ & \multirow{2}{*}{$\begin{array}{c}08.2014 \\
07.2016\end{array}$} \\
\hline & & $14.2-24.5$ & $0.000-0.010$ & $0.0001-0.123$ & $0.000-0.306$ & $0.000-0.010$ & \\
\hline \multirow{2}{*}{$\begin{array}{l}\text { Sum in forest- } \\
\text { steppe zone }\end{array}$} & \multirow{2}{*}{210} & $18.9 \pm 0.4$ & $0.005 \pm 0.001$ & $0.036 \pm 0.003$ & $0.099 \pm 0.009$ & $0.004 \pm 0.001$ & \multirow{2}{*}{-} \\
\hline & & $6.5-42.5$ & $0.000-0.012$ & $0.000-0.411$ & $0.000-0.887$ & $0.000-0.040$ & \\
\hline & & & & teppe zone & & & \\
\hline & & $18.3 \pm 1.2$ & 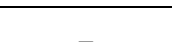 & $0.001 \pm 0.001$ & $0.001 \pm 0.001$ & $0.001 \pm 0.00$ & \\
\hline 7 & 3 & $16.5-20.5$ & - & $0.000-0.002$ & $0.000-0.003$ & $0.000-0.003$ & 11.2014 \\
\hline & & $25.8 \pm 0.5$ & $0.007 \pm 0.001$ & $0.011 \pm 0.001$ & $0.046 \pm 0.003$ & $0.004 \pm 0.0005$ & \\
\hline 8 & 57 & $12.5-33.0$ & $0.000-0.016$ & $0.000-0.032$ & $0.000-0.133$ & $0.000-0.016$ & 05.2015 \\
\hline & & $19.3 \pm 0.9$ & $0.005 \pm 0.002$ & $0.013 \pm 0.003$ & $0.057 \pm 0.011$ & & 09.2015, \\
\hline 9 & 14 & $13.0-25.5$ & $0.000-0.012$ & $0.000-0.041$ & $0.009-0.159$ & - & $4.2016,10.2016$ \\
\hline & & & & teppe zone & & & \\
\hline 10 & & $18.6 \pm 0.5$ & $0.007 \pm 0.001$ & $0.016 \pm 0.002$ & $0.065 \pm 0.008$ & 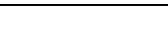 & 092015 \\
\hline 10 & 33 & $12.5-28.5$ & $0.000-0.031$ & $0.000-0.055$ & $0.004-0.212$ & - & 09.2015 \\
\hline & & $19.7 \pm 0.8$ & $0.008 \pm 0.004$ & $0.027 \pm 0.008$ & $0.124 \pm 0.040$ & $0.003 \pm 0.001$ & 092015 \\
\hline 11 & 7 & $17.0-22.5$ & $0.000-0.029$ & $0.006-0.060$ & $0.024-0.316$ & $0.000-0.007$ & 09.2015 \\
\hline & & $20.1 \pm 1.3$ & $0.010 \pm 0.002$ & $0.029 \pm 0.004$ & $0.108 \pm 0.013$ & $0.010 \pm 0.002$ & 09.2015, \\
\hline 12 & 20 & $15.0-38.0$ & $0.004-0.020$ & $0.007-0.064$ & $0.028-0.219$ & $0.000-0.027$ & 04.2016 \\
\hline Sum in the & & $19.2 \pm 0.5$ & $0.007 \pm 0.0005$ & $0.021 \pm 0.002$ & $0.086 \pm 0.009$ & $0.005 \pm 0.001$ & - \\
\hline steppe zone & 134 & $12.5-38.0$ & $0.000-0.031$ & $0.000-0.064$ & $0.004-0.316$ & $0.000-0.027$ & - \\
\hline Sum in & & $20.1 \pm 0.3$ & $0.007 \pm 0.001$ & $0.028 \pm 0.002$ & $0.085 \pm 0.006$ & $0.004 \pm 0.0004$ & \\
\hline all zones & 344 & $6.5-42.5$ & $0.000-0.031$ & $0.000-0.411$ & $0.000-0.887$ & $0.000-0.040$ & - \\
\hline
\end{tabular}

Note: the Table shows the average values of $\mathrm{Hg}$ concentrations with standard errors $(\mathrm{x} \pm \mathrm{SE})$, as well as the ranges.

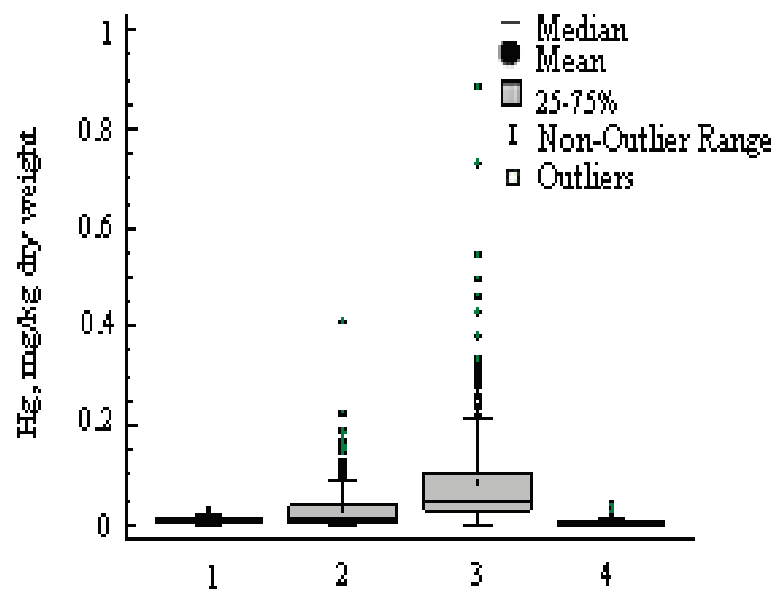

Fig. 1. Hg concentrations in the organs of Myodes glareolus: 1 - muscle, 2 - liver, 3 -kidneys, 4 - brain; median, mean, $25-75 \%$ quartiles, non-outlier range and outliers are shown uniformly in all figures

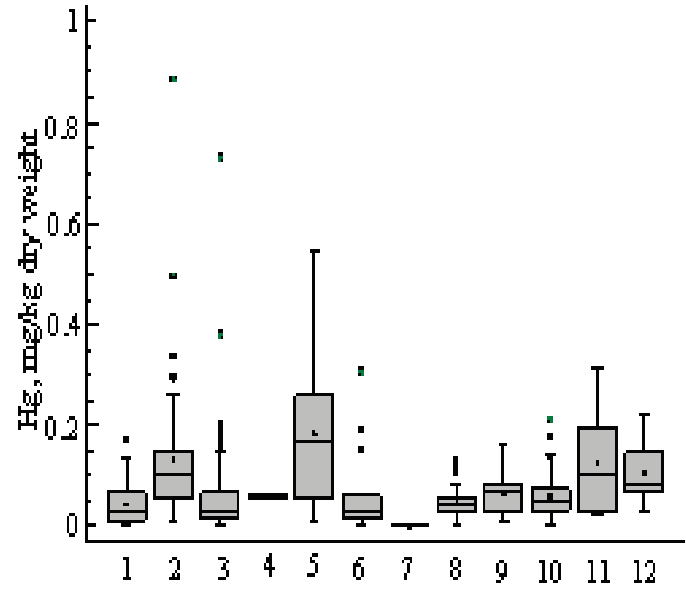

Fig. 2. Hg concentrations in the kidneys of Myodes glareolus from different districts of Voronezh region: district numbers are the same as in Table 1 


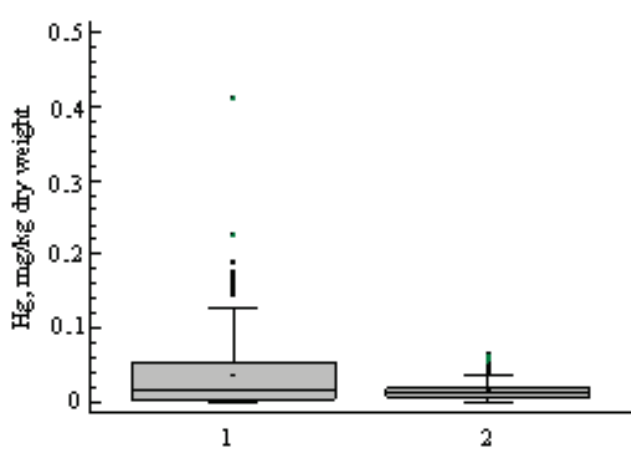

Fig. 3. Hg concentrations in the liver of Myodes glareolus from the forest-steppe and steppe zones of Voronezh region: 1 - forest-steppe, 2 - steppe

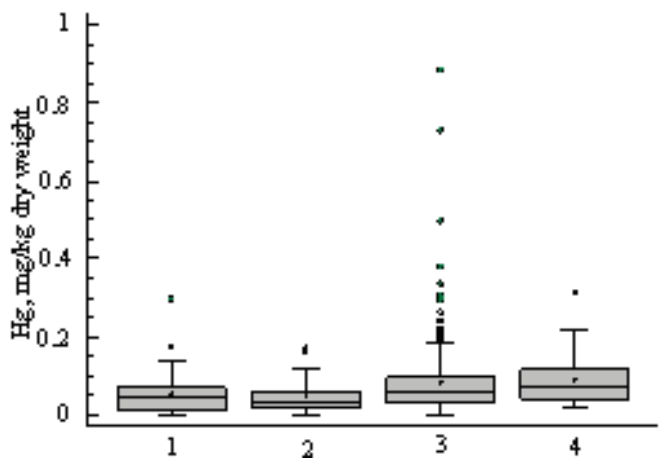

Fig. 4. Hg concentrations in the kidneys of Myodes glareolus from different biotopes: 1 -meadow, 2 - pine forest, 3 -mixed forest, 4 - shrub thickets

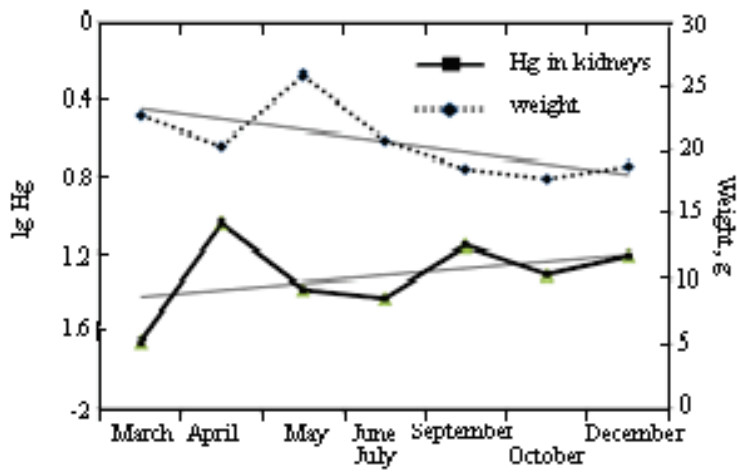

Fig. 5. Time history and the trend lines in average body mass of Myodes glareolus and $\mathrm{Hg}$ concentrations

The data obtained in this study and those available from the literature about the patterns of mercury distribution in the body tissues of small mammals are similar: $\mathrm{Hg}_{\text {kidneys }}>\mathrm{Hg}_{\text {liver }}>\mathrm{Hg}_{\text {muscle }}>\mathrm{Hg}_{\text {brain }}$ (Jeffries \& French, 1976; Komov et al., 2017). Concentrations of Hg in the muscle tissue of the bank voles did not exceed the values for the kidneys and liver, although this is not always the case as is known from the literature (Bull et al., 1977). The same applies to the correlations between the metal content in the studied organs. In some combinations, (for example, for pairs "liver - muscle", "liver - brain", etc.) their presence is noted for both rodents and insectivores (Vucetich et al., 2001). $\mathrm{Hg}$ concentration was negatively correlated with animal body mass, which can be explained by the intensive growth and short life cycle of voles (a "dilution" of accumulated metal). The literature data on the positive correlation between these indicators (Gerstenberger et al., 2006) show that the process of $\mathrm{Hg}$ accumulation by living organisms is affected by many factors, acting with different strengths and not always unidirectionally.

The amount of metal accumulated by voles depends on the characteristics of their biotopes, in particular, moisture content, quantity and diversity of food resources. The main source of intake of organomercury compounds into trophic networks (including terrestrial ones) is the aquatic environment, because in water bodies, wetlands and hyperhumid areas favourable conditions for the bacterial process of conversion of less toxic inorganic metal compounds into more toxic derivatives of methylmercury are created (Greenfield et al., 2001; Coleman et al., 2015). $\mathrm{Hg}$ concentrations in the liver and kidneys of animals from the forest-steppe zone $(\mathrm{Kh}>1)$ was higher than in the steppe zone $(\mathrm{Kh}<1)$, with the exception of voles from one district, which could be associated with time of sampling (season).

While analysing the indices by biotope, the mercury content in the liver of rodents caught in the pine forest was significantly lower than in the meadow, mixed forest and bush thickets. In the kidneys of animals from meadows and from the pine woods it was lower than in bushdwelling animals. Earlier it was shown that $\mathrm{Hg}$ concentrations in the organs of the bank voles from the Voronezh Nature Reserve did not depend on the values of this indicator for the respective soils of their habitats (meadow, alder grove, oak grove, aspen wood, pine wood) in contrast to the shrews, in which this correlation was statistically significant (Komov et al., 2010). Mercury transport performed by small mammals occurs from both aquatic (detritus) and terrestrial (soil) sources. In the first case, it uses the chain of "detritus - aquatic and terrestrial detritivorous invertebrates - predatory invertebrates - insectivorous mammals". In the second one, the chain is "soil - plants - herbivorous invertebrates - omnivorous mammals", with some intersections of separate links at different levels (Talmage \& Walton, 1993). In the terrestrial, as well as in aquatic ecosystems, omnivorous animals (bank vole, a rodent) accumulate the metal in smaller amounts than carnivorous ones (common shrew, an insectivore), because their food items contain less $\mathrm{Hg}$ (Topashka-Ancheva et al., 2003; Rimmer et al., 2010). This is due to the low rate of metal transfer from soil to plants (Talmage \& Walton, 1993) and its uneven distribution by plant organs (less in fruits and seeds than in roots and leaves). The amount of $\mathrm{Hg}$ accumulated by an animal may depend on which parts of the plant it prefers to consume.

The main food of voles is green plants (summer-autumn), with seeds in second place (Emel'yanova, 2008). The summer-autumn, the diet of the animals is supplemented with seeds, flowers, berries (up to the level of consumption of seeds), and mushrooms. Secondary food components include bark, rhizomes, buds, mosses, lichens and animal food. It is possible that the study of the animal's food supply and the metal content in the objects that constitute it would clarify the causes of differences in the accumulation of $\mathrm{Hg}$ by voles from different biotopes.

The increase in the metal content in the organs of voles from the spring-summer to autumn samples is associated with an increase in the number of the given year's offspring in the samples and a decrease in mass indices (the mercury content and animal mass correlate negatevely). The fecundity of voles is high: 3-4 broods per year with 5-6 offspring in each. The young from the first brood have time for producing up to 3 broods during the summer, from the second one $-1-2$ broods, and in the third one (in favourable years) -1 only. The maximum number of animals is observed in late summer and is determined by the productivity sufficient for the survival of individuals born throughout the season.

\section{Conclusion}

Concentrations of $\mathrm{Hg}$ in the organs of the bank voles in Voronezh region is comparable with metal content in the bodies of other rodents that live in uncontaminated territories of the European part of Russia. The main patterns of the distribution of mercury in organs established for mammalian species also apply to voles: $\left[\mathrm{Hg}_{\text {kidneys }}\right]>\left[\mathrm{Hg}_{\text {liver }}\right]>$ $\left[\mathrm{Hg}_{\text {muscle }}\right]>\left[\mathrm{Hg}_{\text {brain }}\right]$.

The highest metal content was observed for animals from the forest-steppe zone inhabiting mixed forests and bushes. The lowest one was found in rodents from the steppe zone inhabiting pine forests. Within the boundaries of the steppe zone, the concentration of $\mathrm{Hg}$ in the kidneys of the voles living in floodplain forests was lower than for those living in scrub habitats. Significant differences in $\mathrm{Hg}$ concentrations revealed in the liver and kidneys of rodents from the forest-steppe and 
steppe zones of the region, as well as from different biotopes (meadow, pine and mixed forest, floodplain shrub thickets), are associated with different moisture content and characteristics of the nutritive base of a particular habitat. During the vegetative season (lasting in Voronezh region from March to November) the average weight of voles in the samples decreased due to the high fertility of animals and recruitment of numerous offspring into the population, while the concentration of $\mathrm{Hg}$ in the liver and kidneys increased.

The work was supported by the RAS Presidium programme "Biological Resources".

\section{References}

Bull, K. R., Roberts, R. D., Inskip, M. J., \& Goodman, G. T. (1977). Mercury concentrations in soil, grass, earthworms and small mammals near an industrial emission source. Environmental Pollution, 12, 135-140.

Coleman, W. J. K., Engstrom, D. R., Mitchel, C. P. J., Swain, E. B., Monson, B. A., Balogh, S. J., Jeremiason, J. D., Branfireun, B. A., Kolka, R. K., \& Almendinger, J. E. (2015). The effects of hydrologic fluctuation and sulfate regeneration on mercury cycling in an experimental peatland. Journal of Geophysical Research: Biogeosciences, 120, 1697-1715.

Cristol, D. A., Brasso, R. L., Condon, A. M., Fovargue, R. E., Friedman, S. L., Hallinger, K. K., Monroe, A. P., \& White, A. E. (2008). The movement of aquatic mercury through terrestrial food webs. Science, 320, 335-335.

Eagles-Smith, C. A., Wiener, J. G., Eckley, C. S., Willacker J. J., Evers, D. C., Marvin-DiPasquale, M., Obrist, D., Fleck, J. A., Aiken, G. R., Lepak, J. M., Jackson, A. K., Webster, J. P., Stewart, A. R., Davis, J. A., Alpers, C. N., \& Ackerman, J. T. (2016). Mercury in western North America: A synthesis of environmental contamination, fluxes, bioaccumulation, and risk to fish and wildlife. Science of the Total Environmenm, 568, 1213-1226.

Emel'yanova, A. A. (2008). Pitanie evropejskoj ryzhej polyovki verhovij Volgi i smezhnyh territorij. [ Feeding of bank vole in the upper Volga and adjacent territory ]Vestnik TvGU, Seriya Biologiya i Ekologiya, 10, 109-117 (in Russian).

Fedotov, V. I. (Ed.). (2013). Ekologo-geograficheskij atlas-kniga Voronezhskoj oblasti. [ Ecological-geographic atlas of Voroneezh oblast ]Izdatel'stvo Voronezhskogo Gosuniversiteta, Voronezh (in Russian).

Gann, G. L., Powell, C. H., Chumchal, M. M., \& Drenner, R. W. (2015). Hg-contaminated terrestrial spiders pose a potential risk to songbirds at Caddo Lake (Texas. Louisiana, USA). Environmental Toxicology and Chemistry, 34, 303-306.

Gerstenberger, S. L., Cross, C. L., Divine, D. D., Gulmatico, M. L., \& Rothweiler, A. M. (2006). Assessment of mercury concentrations in small mammals collected near Las Vegas, Nevada, USA. Environmental Toxicology, 21, 583-589.

Gilmour, C. C., Podar, M., Bullock, A. L., Graham, A. M., Brown, S. D., Somenahally, A. C., Johs, A., Hurt, R. A. Jr., Bailey, K. L., \& Elias, D. A. (2013). Mercury methylation by novel microorganisms from new environments. Environmental Science and Technology, 47, 11810-11820.

Greenfield, B. K., Hrabik, T. R., Hervey, C. J., \& Carpenten, S. R. (2011). Predicting mercury levels in yellow perch of water chemistry, trophic ecology and spatial traits. Canadian Journal of Fisheries and Aquatic Sciences, 58(7), 1419-1429.

Hsu-Kim, H., Kucharzyk, K. H., Zhang, T., \& Deshusses, M. A. (2013). Mechanisms regulating mercury bioavailability for methylating microorganisms in the aquatic environment: A critical review. Environmental Science and Technology, 47, 2441-2456.

Kolka, R. K., Mitchell, C. P. J., Jeremiason, J. D., Hines, N. A., Grigal, D. F., Engstrom, D. R., Coleman-Wasik, J. K., Nater, E. A., Swain, E. B., Monson, B. A., Fleck, J. A., Johnson, B., Almendinger, J. E., Branfireun, B. A., Brezonik, P. L., \& Cotner, J. B. (2011). Mercury cycling in peatland watersheds. Peatland biogeochemistry and watershed hydrology at the Marcell Experimental Forest. CRC Press, Boca Raton.
Komov, V. T., Gremyachirh, V. A., Sapel'nikov, S. F., \& Udodenko, Y. G. (2010). Soderzhanie rtuti v pochvah i v melkih mlekopitayushchih razlichnyh biotopov Voronezhskogo zapovednika [ Content of mercury in soils and small mammals in different biotopes of Voronezh Nature Reserve ] [Rtut' v biosfere: Ekologo-geohimicheskie aspekty]. GEOHI RAN, Moscow. Pp. 281283 (in Russian).

Komov, V. T., Ivanova, E. S., Poddubnaya, N. Y., \& Gremyachikh, V. A. (2017). Mercury in soil, earthworms and organs of voles Myodes glareolus and shrew Sorex araneus in the vicinity of an industrial complex in Northwest Russia (Cherepovets). Environmental Monitoring and Assessment, 189, 104.

Lindberg, S., Bullock, R., Ebinghaus, R., Engstrom, D., Feng, X., Fitzgerald, W., Pirrone, N., Prestbo, E., \& Seigneur, C. (2007). A synthesis of progress and uncertainties in attributing the sources of mercury in deposition. Ambio, 36(1), 19-32.

Mason, R. P., \& Sheu, G. R. (2002). Role of the ocean in the global mercury cycle. Global Biogeochemical Cycles, 16(4), 1093.

Oswald, C. J., Heyes, A., \& Branfireun, B. A. (2014). Fate and transport of ambient mercury and applied mercury isotope in terrestrial upland soils: Insights from the metaalicus watershed. Environmental Science and Technology, 48, 1023-1031.

Rimmer, C. C., Miller, E. K., McFarland, K. P., Taylor, R. J., \& Faccio, S. D. (2010). Mercury bioaccumulation and trophic transfer in the terrestrial food web of a montane forest. Ecotoxicology, 19(4), 697-709.

Rutkowska, M., Bajger-Nowak, G., Kowalewska, D., Bzoma S., Kalisińska, E. Namieśnik, J., \& Konieczka, P. (2019). Methylmercury and total mercury content in soft tissues of two birdspecies wintering in the Baltic Sea near Gdansk, Poland. Chemosphere, 219, 140-147.

Petkovsek, S. A., Kopusar, N., \& Krystufek, B. (2014). Small mammals as biomonitors of metal pollution: A case study in Slovenia. Environmental Monitoring and Assessment, 186, 4261-4274.

Sánchez-Chardi, A., \& López-Fuster, M. (2009). Metal and metalloid accumulation in shrews (Soricomorpha, Mammalia) from two protected Mediterranean costal sites. Environmental Pollution, 157, 1243-1248.

Sánchez-Chardi, A., Ribeiro, C. A. O., \& Nadal, J. (2009). Metals in liver and kidneys and the effects of chronic exposure to pyrite mine pollution in the shrew Crocidura russula inhabiting the protected wetland of Doñana. Chemosphere, 76, 387-394.

Selin, N. E. (2009). Global biogeochemical cycling of mercury: A review. Annual Review of Environment and Resources, 34(1), 43-63.

Shchipanov, N. A., Kupcov, A. V., Kalinin, A. A., Demidova, T. B., Olejnichenko, V. Y., Lyapina, M. G., Aleksandrov, D. Y., Raspopova, A. A., Pavlova, S. V., \& Tumas'yan, F. A. (2010). Melkie mlekopitayushchie yugo-vostoka Tverskoj oblasti. Soobshchenie 1. Fauna i biotopicheskoe raspredelenie. [ Small mammals of southeast Tver oblast . Report 1. Fauna and biotopic distribution ] Sibirskij Ekologicheskij Zhurnal, 17(5), 799-806 (in Russian).

Sneddon, J., Clement, R., Riby, P., \& Lepp, N. W. (2009). Source-pathway-receptors investigation of the fate of trace elements derived from shot-gun pellets discharged in terrestrial ecosystems managed for game shooting. Environmental Pollution, 157, 2663-2669.

Talmage, S. S., \& Walton, B. T. (1993). Food chain transfer and potential renal toxicity of mercury to small mammals at a contaminated terrestrial field site. Ecotoxicology, 2, 243-256.

Tavshunsky, I., Eggert, S. L., \& Mitchell, C. P. J. (2017). Accumulation of methylmercury in invertebrates and masked shrews (Sorex cinereus) at an upland forest-peatland interface in Northern Minnesota, USA. Bulletin of Environmental Contamination and Toxicology, 99(6), 673-678.

Tjerngren, I., Karlsson, T., Bjorn, E., \& Skyllberg, U. (2012). Potential Hg methylation and $\mathrm{MeHg}$ demethylation rates related to the nutrient status of different boreal wetlands. Biogeochemistry, 108, 335-350.

Topashka-Ancheva, M., Metcheva, R., \& Teodorova, S. (2003). A comparative analysis of the heavy metal loading of small mammals in different regions of Bulgaria II: Chromosomal aberrations and blood pathology. Ecotoxicology and Environmental Safety, 54(2), 188-193.

Vucetich, L. M., Vucetich, J. A., Cleckner, L. B., Gorski, P. R., \& Peterson, R. O. (2001). Mercury concentration in deer mouse (Peromyceus maniculatus) tissues from Isle Royale National Park. Environmental Pollution, 114, 113-118. 